\title{
IMPLEMENTATION OF CERTIFICATION SCHEMES IN THE BALKAN AGRO-FOOD SECTOR
}

\author{
Dragan Ćoćkalo ${ }^{1}$, Dejan Đorđević ${ }^{2}$, Mila Kavalić3, Cariša Bešićc \\ *Corresponding authorE-mail: dragan.cockalo@tfzr.rs
}

\begin{tabular}{l} 
A R T I C L E I N F O \\
Original Article \\
Received: 18 October 2018 \\
Accepted: 20 December 2018 \\
doi:10.5937/ekoPolj1901077C \\
UDC 006.83:338.439(497) \\
\hline
\end{tabular}

Keywords:

Certification schemes, Agrofood sector, Competitiveness, Europe, Balkan countries.

JEL: D24, Q13, Q18.

\begin{abstract}
A B S T R A C T
Standardization and the use of certification schemes affect economy competitiveness in general, and therefore the agro-food sector as well - certification according to quality standards is a pre-condition for increasing the competitiveness of agro-food industry. Implementation of quality assurance systems in the agro-food sector and in the retail chains of the Balkan countries are covered in this paper. The Balkan countries mainly focus on the mandatory standards, whereas the non-mandatory ones are almost exclusively used by the country market leaders. It is also the case with the retail chains which by expanding their network also expand the range of standards, and therefore increase the level of competitiveness. This paper provides the information on standardization and implementation of certification schemes in the agro-food industry and retailers in the Balkan Region, also connection of competitiveness and implementation of standards. As the authors of this review know, the consolidated data of this type have not been presented yet.
\end{abstract}

(C) 2019 EA. All rights reserved.

\section{Introduction}

Private food standards and regulations differ from one another per complacency extent: some of them are voluntary while the others are compulsory. Private standards are developed as a response to consumer concerns, primarily as the means of competitive

1 Dragan Ćoćkalo, Ph.D., Full Professor, University of Novi Sad, Technical faculty "Mihajlo Pupin" in Zrenjanin, 23000 Zrenjanin, Đure Đakovića bb, Republic of Serbia. Phone: +381 62 80197 41, E-mail: dragan.cockalo@tfzr.rs ORCID ID (http://orcid.org/0000-0003-2085-5420)

2 Dejan Đorđević, Ph.D., Full Professor, University of Novi Sad, Technical faculty "Mihajlo Pupin" in Zrenjanin, 23000 Zrenjanin, Đure Đakovića bb, Republic of Serbia. Phone: +381 6280197 26, E-mail: dejan.djordjevic@tfzr.rs ORCID ID (https://orcid.org/0000-0001-9453-9207)

3 Mila Kavalić, M.Sc., Assistant, University of Novi Sad, Technical faculty "Mihajlo Pupin" in Zrenjanin, 23000 Zrenjanin, Đure Đakovića bb, Republic of Serbia. Phone: +381 63531 636, E-mail: milazakin@gmail.com

4 Cariša Bešić, Ph.D., Full Professor, University of Kragujevac, Faculty of technical science Čačak, 32000 Čačak, Svetog Save 65, Republic of Serbia. Phone: +381 6036996 96, E-mail: carisa.besic@sbb.rs ORCID ID (https://orcid.org/0000-0001-5370-5328) 
placement for agro-food products of high value on the markets (Henson and Reardon, 2005). Another difference is in terms of their geographic area, (Gavron and Theuvsen, 2009). There are also individual standards such as Nature's Choice (Tesco), Filières Qualité, Field-to-Fork and collective national and international standards, Assured Food Standards, Qualitat Sicherheit and Farm Assured British Beef and Lamb as the examples for former and International Food Standard, Marine Stewardship Council, Forest Stewardship Council and GLOBALG.A.P. as the examples of latter international standards. Many different retailer control schemes were designed to meet this new legal obligation. Some liability schemes in Europe include the British Retail Consortium (BRC) standard and the International Food Standard (IFS), but Safe Quality Food Institute (SQF) standard, HACCP and ISO 22000 also operate in the EU market. Complementarity with HACCP is one out of ten reasons for implementation of ISO 22000 (Escanciano and Santos-Vijande, 2014). These private standards have evolved in response to regulatory developments and, more directly, consumer concerns, and as means of competitive positioning on the markets for high-value agricultural and food products. Thus, private rather than public standards are becoming predominant drivers of agro-food systems (Henson and Hooker, 2001). Further, while this phenomenon is well-established in industrialised countries, private standards are quickly becoming a global phenomenon, not only in the context of the international trade but also within developing country agro-food markets (Reardon et al., 1999; Reardon and Berdegue, 2002). Theuvsen, Plumeyer and Gawron (2007) argued that certification schemes affected sharing information in food supply chains and, therefore, had a strong effect on their competitiveness. Carter et al. (2018) investigating online buying experience, through an internet-enabled collective intelligence (CI) on how, what and why decisions were made to purchase food and apparel. Interesting study was conducted by authors Šapić et al. (2018) which investigated prestige and national identity as predictors of food products purchase. Also, useful can be study by authors Dumitrescu \& Oana (2018) which analysed judgments and decision making in consumer behavior

We agree with the statement "as growing numbers of retailers request private standards, the standard is no longer an element of competitiveness, but simply a tool to stay on the market" (Rossignoli and Moruzzo, 2014), but this statement doesn't mean the same in the Balkans. In our opinion, there is a significant potential in the observed area. It seems that the Balkan region provides "sufficient diversity" starting points and pretensions in relation to regional, EU and global market and according to EU food safety certification schemes, harmonization efforts, systematic quality assurance and improved traceability are considered cornerstones for improving the competitiveness of European agro-business. The most prevalent schemes in the Balkan countries are: ISO 9001, ISO 14001, HACCP, GLOBAL G.A.P., ISO 22000, BRC Global Standard, Demeter and PDO/PGI/TSG systems, (Bešić et al., 2015).

\section{Materials and methods}

Competitiveness of the national agro-food sector is based on the use of quality standards in the supply chain. A stronger orientation in the Balkan countries agro-food sector towards EU and the world market export have resulted in the larger number 
of certified companies. On the other hand, if the tendency is in favour of regional competitiveness, the number of certificates is smaller - which is the case in Serbia. It means that stimulating national certification according to quality standards is a prerequisite for increasing the competitiveness of agro-food industry. International retailers have a significant role here, requiring suppliers' use of certain standards as a default. The productivity factor can also be linked to competitiveness, especially in the agricultural sector, where the number of employees and the size of a property also play a significant role. A review of the realised income, directly related to the retailers' competitiveness, is also the subject of this paper.

This research is based on analysis of the implementation of quality assurance systems in the Balkan agro-food sector, and on the implementation of standards on the Balkan retail market as well. By using a descriptive approach and a tabular comparison we have intended to establish the connection of agro-food sector in the Balkan region regarding competitiveness and the implementation of standards.

The research was carried out from 2015 to 2017, resulting in a selection of significant data for the aforementioned and preceeding years. Data and analyses available online have been reviewed, including FAO, Eurostat, OECD, EU Commision, WEF, IDK, GFK, Deloitte, the World Bank, local statistics office data, available data on certification schemes and their use, as well as the available relevant reports by the local Ministries. The retail chains were contacted with the aim to check their existing certificates. The chosen chains were ranked by IGD rank, distinguishing the chains by their realised income. As a characteristic competitiveness indicator, due to the limited number of comparable data, Revealed Comparative Advantage (RCA) was used, just like in retail, to show the mutual competitiveness in food industry of the Balkan countries, as well as the NEI (Net Export Index) to compare the competitive position of the region's agriculture.

\section{Implementation of certification schemes in the Balkan countries}

Being in the centre of the supply chain, consumers can choose among a multitude of retailers and, in that way, they induce retailers to innovate their products and services, reduce prices, give discounts or offer other benefits to consumers. Therefore, it seems that key to success lies in investing in competitive and reliable supply chains which know how to satisfy consumer requirements. Unfair activities could damage their ability to offer a wide range of products and considerably weaken their competitive position. On the other hand, a good relationship between retailers and suppliers brings the best benefits to consumers. In such innovative, pleasant and mutually beneficial ambience both suppliers and retailers share plans and common targets and objectives to achieve profitable growth. Suppliers are also trying to offer special products with competitive advantage in order to give additional value to retailers. Nowadays, about 29 million Europeans work in retail and wholesale sector which contributes to quality of life in city centres, small towns and villages, making them more attractive. (EuroCommerce, 2016). 
Speaking about agricultural products, retailers lead in their promotion, mostly through retailer brands. They help in finding new markets for agricultural products and in increasing sale through different promotional activities and investments. Retailers also improve the communication between farmers and consumers by providing farmers with communication tools. There are numerous certification schemes for agricultural products and food that prove the cooperation in the food chain. Retailers also implement quality standards through third party certification schemes such as IFS, BRC, ISO22000, IMQ, ICS BIO, Ecolabel, non-GMO, MCS, ACS etc. and support and promote the development of sustainable agricultural and fishing practices, (EuroCommerce, 2016; Vlahović et al., 2016). Balkan retailers support IFS, Global G.A.P, HACCP and ISO 22000 certification sheme and demand certification from their suppliers. Except the international, there are also lots of local, national and regional retailers who are competing by their offer and quality on this, regarding the price, exceptionally sensitive market. Although with considerable deviations, the minimum requirements that they impose to their suppliers of food products include HACCP standard.

According to Djekic et al. (2011), Djordjevic et al. (2011) also Smigic et al. (2015) in some Western Balkan countries (Serbia, Bosnia and Herzegovina and Macedonia) the implementation of different quality and food safety assurance schemes is either required by law or large multinationals (both producers and retailers) that establish their own schemes and requirements (such as HACCP). However, other private and food quality standards are applied periodically although their implementation and certification is promoted by the governments of these countries. Except HACCP, food safety standard ISO 22000 and QMS ISO 9001 are most commonly implemented in the Balkan countries. It should be mentioned here that food producers in these countries received financial support from different governmental and nongovernmental organizations (USAid, SIEPA and EU funds). Besides HACCP, the most common certifications in the Western Balkan food industry cover food safety (ISO 22000) and quality management systems (ISO 9001).

Combined with ISO 9001 and ISO 14001, ISO 22000 standard represents an equal partner in creation of the integrated management system based on a risk. While observing the application of ISO standards in the Balkan countries, we are focused on the application of ISO 9001, ISO 14001 and ISO 22001. These standards can only be conditionally used in the comparison and analysis of agro sector competitiveness since, according to the available data, the application of these standards worldwide in the sectors such as agriculture, fishing, food products, beverages and tobacco, wholesale $\&$ retail trade, hotels and restaurants, is ranked among top 5 industrial sectors with the highest rate of application. Their application was observed in 2014 and 2015, (see Table 1). Indices are interesting for the following reason - in the Balkan countries, more and more attention is paid not only to the most widespread standard ISO 9001, but the economies are directed to other standards as well, which affects the creation of added value of both products and services. Romania represents the leading country in the application of ISO 9001 and 14001standards, while Greece leads in the application of 
ISO 22001. Montenegro and Albania are the countries with the least application of ISO standard. Serbia is positioned in the middle of the list.

Table 1. Number of ISO 9001, ISO 14001, ISO 22001 certificates in the Balkan countries

\begin{tabular}{|l|r|r|r|r|r|r|}
\hline \multicolumn{1}{|c|}{ Standard } & \multicolumn{1}{c|}{ ISO 9001 certificates } & \multicolumn{1}{c|}{ ISO 14001 certificates } & \multicolumn{2}{c|}{ ISO 22001 certificates } \\
\hline \multicolumn{1}{|c|}{ Year } & $\mathbf{2 0 1 5}$ & $\mathbf{2 0 1 7}$ & $\mathbf{2 0 1 5}$ & $\mathbf{2 0 1 7}$ & $\mathbf{2 0 1 5}$ & $\mathbf{2 0 1 7}$ \\
\hline Total Balkan countries & $\mathbf{4 0 , 1 9 9}$ & $\mathbf{3 2 , 6 4 3}$ & $\mathbf{1 5 , 9 3 7}$ & $\mathbf{1 1 , 7 6 4}$ & $\mathbf{3 , 3 7 9}$ & $\mathbf{3 , 6 2 0}$ \\
\hline Albania & 279 & 215 & 106 & 70 & 12 & 9 \\
\hline Bosnia and Herzegovina & 790 & 1,140 & 149 & 247 & 12 & 19 \\
\hline Bulgaria & 5,441 & 5,397 & 1,484 & 1,820 & 283 & 261 \\
\hline Croatia & 2,529 & 2,381 & 884 & 966 & 98 & 78 \\
\hline Greece & 6,187 & 7,056 & 1,115 & 1,520 & 1,526 & 2,285 \\
\hline Montenegro & 84 & 46 & 17 & 17 & 4 & 8 \\
\hline Romania & 20,524 & 12,031 & 10,581 & 5,555 & 1,171 & 708 \\
\hline Serbia & 2,521 & 2,213 & 1,120 & 887 & 232 & 187 \\
\hline Slovenia & 1,481 & 1,720 & 357 & 450 & 13 & 18 \\
\hline Macedonia & 363 & 444 & 124 & 232 & 28 & 47 \\
\hline
\end{tabular}

Source: ISO, 2017

The Balkan countries are in somewhat similar situation with the former Yugoslav countries. The use of standards is still in its developing phase, the market is still being adjusted to the mandatory standard use and only the leading companies introduce nonmandatory standards in their practice. The predominantly used standard is HACCP, being required not only by law but also by the majority of retailers. The most promising private standard directly related to food in the Balkan Region is Global G.A.P.

A comparative example of standards implementation in agro-food industry and their use in Serbia and the West Balkan countries and the whole Balkans is presenedt in Table 2. Regarding the West Balkan countries, Serbia is a leader in relation to implementation of all schemes of standards. However, regarding other Balkan countries, Serbia lags behind significantly. Apart from GLOBALG.A.P., the implementation of other standards in the Republic of Serbia is low. Comparing to Greece, for example, (which is globally one of the leading counties in this standard implementation), Serbia lags behind considerably. This phenomenon additionally contributes to uncompetitiveness of Serbian companies. It is obvious from the Tables 1 and 2 that other countries from the Balkans, such as Romania and Bulgaria, are more oriented towards ISO certification schemes (generally) than towards GLOBALG.A.P. scheme, while for Serbia (strictly for food safety) the opposite is true. There are several reasons for an insufficient use of standards in Serbian agro-food industry but it seems that the most important one is when a company which implements GLOBALG.A.P. standard has an obligation to perform re-certification every year, which represents a significant financial effort. Moreover, Ministry of Agricuture, Forestry and Water Engineering of the Republic of Serbia has terminated co-funding. 
Three quality logos attest to the specific traditions and qualities of food, agricultural products and wines, aromatised wines and spirits, produced in the European Union or in other countries. Two of these logos - the Protected Designation of Origin (PDO) and the Protected Geographical Indication (PGI) - have a specific link to the region where the product comes from, while the third one - the Traditional Speciality Guaranteed (TSG) - logo highlights a traditional production process. Food products are eligible for all three logos: PDO, PGI and TSG. Wine is eligible for PDO and PGI while spirits and aromatised wines qualified for PGI recognition (see Table 2.). Greece is the leading country in the application of PGI, PDO and TSG. Demeter is a brand for the products from Biodynamic Agriculture. Only strictly controlled and contractually bound partners are permitted to use the Brand. A comprehensive verification process insures strict compliance with the International Demeter Production and Processing Standards, as well as applicable organic regulations in the various countries without a gap, through every step, from agricultural production to processing and final product packaging. The holistic Demeter requirements exceed government mandated regulations. Not only do they exclude the use of synthetic fertilisers and chemical plant protection agents in agricultural crop production, or artificial additives during processing, but they also require very specific measures to strengthen the life processes in soil and foodstuffs. Demeter farmers and processors actively contribute to shaping the future worth living by creating healthy food of distinctive taste, truly "Food with a Character". Demeter - the Brand you can trust to. Slovenia and Greece represent the leading countries in the application of Demeter standard. The Global Competitiveness Report (2016) and Agricultural policy costs are shown in Table 2. Croatia (141), Greece (129) and Serbia (128) are among the leading contries considering Agricultural policy costs. Albania (97) and Serbia (94) are the leaders in relation to competitiveness.

Table 2. Implementation of standards in the Balkan countries

\begin{tabular}{|c|c|c|c|c|c|}
\hline Standards & $\begin{array}{c}\text { GLOBAL } \\
\text { G.A.P. }\end{array}$ & BRC & $\begin{array}{c}\text { PDO/ } \\
\text { PGI/TSG }\end{array}$ & $\begin{array}{c}\text { Demeter } \\
\text { Farms }+ \\
\text { processors }+ \\
\text { distributors }\end{array}$ & $\begin{array}{c}\text { Agricultural } \\
\text { policy costs } \\
\text { WEF }\end{array}$ \\
\hline Total Balkan countries & 11,554 & 409 & 155 & $49+7+5$ & - \\
\hline Albania & 0 & 1 & 0 & 0 & 64 \\
\hline Bosnia and Hercegovina & 269 & 2 & 0 & 0 & 124 \\
\hline Bulgaria & 17 & 29 & 7 & $1+0+1$ & 120 \\
\hline Croatia & 141 & 14 & 13 & $2+0+1$ & 141 \\
\hline Greece & 10,764 & 265 & 106 & $21+6+2$ & 129 \\
\hline Macedonia & 14 & 1 & 0 & 0 & 23 \\
\hline Montenegro & 0 & 0 & 0 & 0 & 27 \\
\hline Romania & 46 & 51 & 4 & $1+0+0$ & 69 \\
\hline Serbia & 281 & 37 & 0 & 0 & 128 \\
\hline Slovenia & 22 & 9 & 25 & $24+1+1$ & 107 \\
\hline
\end{tabular}

Source: QS, 2015; BRC, 2017; EU, 2017; DI, 2017; GLOBALG.A.P., 2012 


\section{Implementation of certification schemes on the Balkan retail market}

Onwards, the Table 3 will present retail chain standards in the Balkan countries. 10 countries with their areas mainly on the Balkan peninsula are included here. Having only $5 \%$ of its area on the Balkans and therefore not being in the focus of our research, Turkey is excluded from this review. Given that the presented countries have suffered numerous economic shocks like transitions, economic crises, wars, they are still in the process of market building. This is particularly the case of former Yugoslav countries. Since the retail chains are increasingly oriented towards growth, the number of their certificates is larger. It is noticed that HACCP standard is the most common one, since its use is mandatory. The retail chains in our focus were chosen on the basis of GDI analysis per income. The majority of the retail chains using non-mandatory standards, the use of ISO 9001, ISO 14001 and Global G.A.L. and IFC is present in a very small proportion. Retail chains using these standards are at the top of the list by their market share and revenue. The overview of the realised income (in EUR) is directly related to the retailers' competitiveness, and the competitiveness of retail chains is reflected in the increased use of standards.

Table 3. Implementation of standards in Balkan retails

\begin{tabular}{|c|c|c|c|c|c|c|c|c|c|c|c|}
\hline Country & $\begin{array}{l}\text { Retail } \\
\text { chains }\end{array}$ & $\begin{array}{c}\begin{array}{c}\text { Realised } \\
\text { income } \\
(, 000 \text { EUR })\end{array} \\
\end{array}$ & $\begin{array}{c}\text { Market } \\
\text { share \% }\end{array}$ & $\begin{array}{c}\text { Store } \\
\text { number }\end{array}$ & $\begin{array}{l}\text { ISO } \\
9001\end{array}$ & $\begin{array}{c}\text { ISO } \\
14001\end{array}$ & НАССР & $\begin{array}{c}\text { ISO } \\
22001\end{array}$ & $\begin{array}{c}\text { GLOBAL } \\
\text { G.A.P. }\end{array}$ & BRC & IFS \\
\hline \multirow{6}{*}{$\mathrm{BiH}$} & Konzum Bih & 781.14 & 8,76 & 234 & - & $\mathrm{x}$ & $\mathrm{x}$ & - & $\mathrm{x}$ & - & - \\
\hline & Bingo & 521.66 & 5,85 & 112 & - & - & $\mathrm{x}$ & - & - & - & - \\
\hline & Tropic & 434.81 & 4,87 & 62 & - & - & $\mathrm{x}$ & - & - & - & - \\
\hline & Interex & 244.17 & 2,74 & 24 & - & - & $\mathrm{x}$ & - & - & - & - \\
\hline & Engrotus & 143.16 & 1,6 & 27 & - & - & $\mathrm{x}$ & - & - & - & - \\
\hline & Robot Komerc & 140.08 & 1,37 & 22 & - & - & $\mathrm{x}$ & - & - & - & - \\
\hline \multirow{7}{*}{ Bulgaria } & $\begin{array}{l}\text { Schwarz } \\
\text { Group } \\
\text { (Kaufland) }\end{array}$ & $2,156.63$ & 11,63 & 151 & - & - & $\mathrm{x}$ & - & - & - & - \\
\hline & Billa Bulgaria & 488.00 & 2,63 & 158 & - & - & $\mathrm{x}$ & - & - & - & - \\
\hline & Fantastico & 357.20 & 1,93 & 40 & - & - & $x$ & - & - & - & - \\
\hline & Marinopoulos & 312.70 & 1,69 & 33 & - & - & $\mathrm{x}$ & - & - & - & - \\
\hline & $\begin{array}{l}\text { Maxima } \\
\text { Bulgaria }\end{array}$ & 169.37 & 0,91 & 61 & - & - & $\mathrm{x}$ & - & - & - & - \\
\hline & Piccadily & 125.00 & 0,67 & 20 & - & - & $\mathrm{x}$ & - & - & - & - \\
\hline & $\begin{array}{l}\text { CBA Asset } \\
\text { Managment }\end{array}$ & 69.60 & 0,38 & 144 & - & - & $\mathrm{x}$ & - & - & - & - \\
\hline \multirow{7}{*}{ Croatia } & \begin{tabular}{|l|}
$\begin{array}{l}\text { Konzum } \\
\text { Croatia }\end{array}$ \\
\end{tabular} & $11,794.10$ & 19,75 & 1,775 & - & $\mathrm{x}$ & $\mathrm{x}$ & - & $\mathrm{x}$ & - & - \\
\hline & $\begin{array}{l}\text { Schwarz } \\
\text { Group } \\
\text { (Lidl) } \\
\end{array}$ & $10,296.42$ & 17,24 & 142 & - & - & $\mathrm{x}$ & - & - & - & - \\
\hline & Plodine & $4,006.40$ & 6,71 & 77 & - & - & $\mathrm{x}$ & - & - & - & - \\
\hline & SPAR Croatia & $2,914.61$ & 4,88 & 57 & - & - & $\mathrm{x}$ & - & - & - & - \\
\hline & Tommy & $2,491.00$ & 4,17 & 191 & - & - & $\mathrm{x}$ & - & - & - & - \\
\hline & Billa Croatia & $1,768.44$ & 2,96 & 97 & - & - & $\mathrm{x}$ & - & - & - & - \\
\hline & KTC & $1,416.40$ & 2,37 & 36 & - & - & $\mathrm{x}$ & - & - & - & - \\
\hline
\end{tabular}




\begin{tabular}{|c|c|c|c|c|c|c|c|c|c|c|c|}
\hline Country & $\begin{array}{l}\text { Retail } \\
\text { chains }\end{array}$ & $\begin{array}{c}\begin{array}{c}\text { Realised } \\
\text { income } \\
(, 000 \text { EUR })\end{array} \\
\end{array}$ & $\begin{array}{l}\text { Market } \\
\text { share \% }\end{array}$ & $\begin{array}{c}\text { Store } \\
\text { number }\end{array}$ & $\begin{array}{l}\text { ISO } \\
9001\end{array}$ & $\begin{array}{c}\text { ISO } \\
14001\end{array}$ & НАСCР & $\begin{array}{c}\text { ISO } \\
22001\end{array}$ & $\begin{array}{c}\text { GLOBAL } \\
\text { G.A.P. }\end{array}$ & BRC & IFS \\
\hline \multirow{6}{*}{ Greeece } & Marinopoulos & $1,833.76$ & 7,25 & 579 & - & - & $\mathrm{x}$ & - & - & - & - \\
\hline & Lidl Greece & 1,726 & 6,82 & 240 & - & - & $\mathrm{x}$ & - & - & - & - \\
\hline & \begin{tabular}{|l} 
Ahold \\
Delhaize \\
Central and \\
Soutbeastern \\
Europe \\
\end{tabular} & $1,612.20$ & 6,37 & 348 & $\mathrm{x}$ & - & $\mathrm{x}$ & - & - & - & - \\
\hline & Sklavenitis & $1,432.60$ & 5,66 & 122 & - & - & $\mathrm{x}$ & - & - & - & - \\
\hline & Metro AEBE & 781.50 & 3,09 & 243 & - & - & $\mathrm{x}$ & - & - & - & - \\
\hline & Masoutis & 620.70 & 2,45 & 246 & - & - & $\mathrm{x}$ & - & - & - & - \\
\hline \multirow{5}{*}{$\begin{array}{l}\text { Macedonia, } \\
\text { FYR }\end{array}$} & VERO & $6,461.64$ & 4,38 & 11 & - & - & $\mathrm{x}$ & - & - & - & - \\
\hline & Tinex & $5,693.07$ & 3,86 & 59 & - & - & $\mathrm{x}$ & - & - & - & - \\
\hline & Engrotus & $3,261.97$ & 2,21 & 14 & - & - & $\mathrm{x}$ & - & - & - & - \\
\hline & $\begin{array}{l}\text { Skopski Pazar } \\
\text { AD } \\
\text { Skoplje } \\
\end{array}$ & $3,021.87$ & 2,05 & 25 & $\mathrm{x}$ & - & $\mathrm{x}$ & - & - & - & - \\
\hline & \begin{tabular}{|l} 
Ramstore \\
Bulgaria \\
\end{tabular} & $1,148.50$ & 0,78 & 20 & $\mathrm{x}$ & - & $\mathrm{x}$ & - & - & - & - \\
\hline \multirow{7}{*}{ Romania } & $\begin{array}{l}\text { Schwarz } \\
\text { Group }\end{array}$ & $15,654.29$ & 10,95 & 329 & - & - & $\mathrm{x}$ & - & - & - & - \\
\hline & \begin{tabular}{|l|} 
Carrefour \\
Romania
\end{tabular} & $6,793.44$ & 4,75 & 278 & - & - & $\mathrm{x}$ & - & - & - & - \\
\hline & \begin{tabular}{|l|l} 
Auchan \\
Romania \\
\end{tabular} & $4,675.87$ & 3,27 & 34 & - & - & $\mathrm{x}$ & - & - & - & - \\
\hline & $\begin{array}{l}\text { Ahold } \\
\text { Delhaize } \\
\text { Central and } \\
\text { Soutbeastern } \\
\text { Europe } \\
\end{array}$ & $3,865.60$ & 2,70 & 580 & $\mathrm{x}$ & - & $\mathrm{x}$ & - & - & - & - \\
\hline & Profi Romania & $3,592.00$ & 2,51 & 501 & - & - & $\mathrm{x}$ & - & - & - & - \\
\hline & Rewe Group & $1,896.77$ & 1,33 & 198 & - & - & $\mathrm{x}$ & - & - & - & - \\
\hline & Cora & $1,758.66$ & 1,23 & 11 & - & - & $\mathrm{x}$ & - & - & - & - \\
\hline \multirow{7}{*}{ Slovenia } & \begin{tabular}{|l} 
Merkator \\
Slovenia
\end{tabular} & $1,364.80$ & 31,23 & 483 & $\mathrm{x}$ & $\mathrm{x}$ & $\mathrm{x}$ & $\mathrm{x}$ & - & - & $\mathrm{x}$ \\
\hline & \begin{tabular}{|l|} 
SPAR \\
Slovenia \\
\end{tabular} & 766.80 & 17,55 & 103 & - & - & $\mathrm{x}$ & - & - & - & - \\
\hline & Engrotus & 461.70 & 10,57 & 302 & - & - & $\mathrm{x}$ & - & - & - & - \\
\hline & \begin{tabular}{|l|l} 
Hofer \\
Slovenia \\
\end{tabular} & 420.00 & 9,61 & 81 & - & - & $\mathrm{x}$ & - & - & - & $\mathrm{x}$ \\
\hline & Lidl Slovenia & 401.00 & 9,18 & 51 & - & - & $\mathrm{x}$ & - & - & - & - \\
\hline & Eurospin & 217.06 & 4,97 & 50 & - & - & $x$ & - & - & - & - \\
\hline & Leclerc & 101.51 & 2,32 & 2 & - & - & $x$ & - & - & - & - \\
\hline
\end{tabular}




\begin{tabular}{|c|c|c|c|c|c|c|c|c|c|c|c|}
\hline Country & $\begin{array}{l}\text { Retail } \\
\text { chains }\end{array}$ & \begin{tabular}{|c|}
$\begin{array}{c}\text { Realised } \\
\text { income } \\
(, 000 \text { EUR })\end{array}$ \\
\end{tabular} & $\begin{array}{c}\text { Market } \\
\text { share \% }\end{array}$ & $\begin{array}{c}\text { Store } \\
\text { number }\end{array}$ & $\begin{array}{l}\text { ISO } \\
9001\end{array}$ & \begin{tabular}{c|} 
ISO \\
14001
\end{tabular} & НАССР & $\begin{array}{c}\text { ISO } \\
22001\end{array}$ & $\begin{array}{l}\text { GLOBAL } \\
\text { G.A.P. }\end{array}$ & BRC & IFS \\
\hline \multirow{7}{*}{ Serbia } & \begin{tabular}{|l|l} 
Ahold \\
Delhaize \\
Central and \\
Soutbeastern \\
Europe \\
\end{tabular} & $127,041.90$ & 12,24 & 409 & $x$ & & $x$ & - & - & - & - \\
\hline & $\begin{array}{l}\text { Merkator } \\
\text { Serbia }\end{array}$ & $100,211.00$ & 9,66 & 332 & $\mathrm{x}$ & $\mathrm{x}$ & $\mathrm{x}$ & - & - & - & - \\
\hline & Dis & $22,835.00$ & 2,20 & 24 & & & $\mathrm{x}$ & - & - & - & - \\
\hline & Univerexport & $22,109.00$ & 2,13 & 189 & $\mathrm{x}$ & - & $\mathrm{x}$ & - & - & - & - \\
\hline & Aman & $12,036.00$ & 1,16 & 200 & - & - & $\mathrm{x}$ & - & - & - & - \\
\hline & Gomex & $10,723.00$ & 1,03 & 170 & - & - & $\mathrm{x}$ & - & - & - & - \\
\hline & Super Vero & $7,062.78$ & 0.68 & 6 & - & - & $\mathrm{x}$ & - & - & - & - \\
\hline \multirow{4}{*}{ Albania } & $\begin{array}{l}\begin{array}{l}\text { Big Market } \\
\text { (Albania) }\end{array} \\
\end{array}$ & 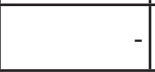 & 37 & 75 & - & - & $\mathrm{x}$ & - & - & - & - \\
\hline & \begin{tabular}{|l} 
Marinopoulos \\
(Greece) \\
(Carrefour \\
franchise) \\
\end{tabular} & & 21 & 15 & - & - & $\mathrm{x}$ & - & - & - & - \\
\hline & Conad (Italia) & - & 29 & 34 & - & - & $x$ & - & - & - & - \\
\hline & \begin{tabular}{|l}
$\begin{array}{l}\text { ECO Market } \\
\text { (Albania) }\end{array}$ \\
\end{tabular} & & 13 & 15 & - & - & $\mathrm{x}$ & - & - & - & - \\
\hline \multirow{4}{*}{ Montenegro } & \begin{tabular}{|l|} 
Expo \\
(Montenegro) \\
(Delhaize \\
franchise) \\
\end{tabular} & & & & $\mathrm{x}$ & - & $\mathrm{x}$ & - & - & - & - \\
\hline & $\begin{array}{l}\text { Roda (ex. } \\
\text { Mercator) } \\
\text { (Agrokor, } \\
\text { Croatia) } \\
\end{array}$ & & 45 & 103 & $\mathrm{x}$ & $\mathrm{x}$ & $\mathrm{x}$ & $\mathrm{x}$ & - & - & - \\
\hline & \begin{tabular}{|l|} 
Voli \\
(Montenegro)
\end{tabular} & & 30 & 61 & $x$ & - & $\mathrm{x}$ & - & - & - & - \\
\hline & \begin{tabular}{|l|} 
Lakovic \\
D.O.O
\end{tabular} & & 25 & 22 & $\mathrm{x}$ & - & $\mathrm{x}$ & - & - & - & - \\
\hline
\end{tabular}

Source: Authors' own research (the data for 2017.)

\section{Discussion and conclusions}

Competitiveness of agro-food sector in the Balkan countries is based on the increased use of quality standards in the retail chains. A stronger orientation of a country's agrofood sector towards EU and world market export results in the larger number of certified companies. On the other hand, if the tendency is in favour of regional competitiveness, the number of certificates is smaller - which is the case in Serbia. This means that stimulating national certification according to quality standards is a prerequisite for increasing competitiveness of agro-food industry.

The Balkan countries mainly focus on the mandatory standards, whereas the nonmandatory ones are almost exclusively used by the country market leaders only. The leaders in the agro sector have realised their objective to be competitive by using standards and adding value to customers on one side, and by increasing the export on the other side. The more focused a provider is to expand their network and export, 
the more they use the standards. This is also the case with the retail chains, which by expanding their network, expand the range of standards and therefore increase the level of competitiveness. International retailers have a significant role here, requiring suppliers' use of certain standards as a default, and therefore directly stimulating the rise in the use of standards and good practice.

Several important prerequisits can be distinguished in improving competitiveness of both agro-sector and retail chains: (1) harmonisation of practice with the quality system ISO 9000 standards and technical regulations; (2) quality certification of domestic companies and its correlation with export results - the role of quality certificates in practice; (3) foreign customers and their requirements related to the product quality; (4) WTO; (5) ISO 14000 - standards in the field of ecology.

\section{Conflict of interests}

The authors declare no conflict of interest.

\section{References}

1. Bešić, C., Bogetić, S., Ćoćkalo, D., \& Đorđević, D. (2015). The Role of Global G.A.P in Improving Competitiveness of Agro-food Industry. Ekonomika poljoprivrede (Economics of Agriculture), 62(3), 583-597.

2. BRC. (2017). BRC Directory Retrieved 03.02.2017, from http://www.brcdirectory.com/

3. Carter, S., \& Yeo, A. C. M. (2018). Internet-enabled Collective Intelligence as a Precursor and Predictor of Consumer Behaviour, Economics, Management, and Financial Markets, 13(4): 11-38.

4. DI. (2017). Certified Demeter operations. Retrieved 05.02.2017, from DemeterInternational (DI) http://www.demeter.net/statistics

5. Djekic, I., Tomasevic, I., \& Radovanovic, R. (2011). Quality and food safety issues revealed in certified food companies in three Western Balkans countries. Food Control, 22(11), 1736-1741.

6. Djordjevic, D., Cockalo, D., \& Bogetic, S. (2011). An analysis of the HACCP system implementation - The factor of improving competitiveness in Serbian companies. African Journal of Agricultural Research, 6(3), 515-520.

7. EBRD, ETF, SEECEL, EU, \& OECD. (2016). SME Policy Index: Western Balkans and Turkey (Publication no. 10.1787/9789264254473-en). Retrieved 05.05.2017, from EBRD, ETF, SEECEL, EU, OECD https://europa.ba/wp-content/ uploads/2016/06/SME-Policy-Index-Western-Balkans-and-Turkey-2016.pdf

8. Escanciano, C., \& Santos-Vijande, M. L. (2014). Reasons and constraints to implementing an ISO 22000 food safety management system: Evidence from Spain. Food Control, 40, 50-57.

9. EU. (2017). DOOR database ("Database of Origin and Registration"). Retrieved 03.05.2017 http://ec.europa.eu/agriculture/quality/door/list.html 
10. EuroCommerce. (2016). Retail and agriculture: Contribution to the agri-markets task force. Retrieved 05.05.2017., from EuroCommerce http://www.eurocommerce.eu/ media/130179/agri_markets_task_force_contribution_-_final_version.pdf

11. Gawron, J.-C., \& Theuvsen, L. (2009). Certification schemes in the European agrifood sector: Overview and opportunities for Central and Eastern Europe. Outlook on Agriculture, 38(1), 9-14.

12. GLOBALG.A.P. (2012a). GLOBALG.A.P. Annual Report 2012. Retrieved 02.02.2015, from GLOBALG.A.P. http://www.globalgap.org/export/sites/default/. content/.galleries/documents/130124_AR12_web_en.pdf

13. Hatanaka, M., Bain, C., \& Busc, L. (2005). Third-party certification in the global agrifood system. Food policy, 30(3), 354-369.

14. Henson, S., \& Hooker, N. H. (2001). Private sector management of food safety: public regulation and the role of private controls. The International Food and Agribusiness Management Review, 4(1), 7-17.

15. Henson, S., \& Reardon, T. (2005). Private agri-food standards: Implications for food policy and the agri-food system. Food policy, 30(3), 241-253.

16. ISO. (2018). The ISO Survey 2017. Retrieved 05.05.2018, from ISO https://www. iso.org/the-iso-survey.html

17. Mirică, C. O. (2018). Judgments and Decision Making in Consumer Behavior: The Use of Psychophysiological Measures to Investigate Emotions and Cognitive Responses, Economics, Management, and Financial Markets 13(4): 39-44.

18. QS. (2015). Annual Report 2012 - Outlook 2013. Retrieved 03.02.2015, from QS Qualität und Sicherheit GmbH https:/www.q-s.de/services/files/mediencenter/ publikationen/QS Annual Report-ES_2013.pdf

19. Reardon, T., \& Berdegué, J. A. (2002). The rapid rise of supermarkets in Latin America: challenges and opportunities for development. Development Policy Review, 20(4), 371-388.

20. Reardon, T., Codron, J.-M., Busch, L., Bingen, J., \& Harris, C. (1999). Global change in agrifood grades and standards: agribusiness strategic responses in developing countries. The International Food and Agribusiness Management Review, 2(3-4), 421-435.

21. Rossignoli, C. M., \& Moruzzo, R. (2014). Retail Power and Private Standards in the Agri-Food Chain. Agroecology and sustainable food systems, 38(9), 1108-1124.

22. Smigic, N., Rajkovic, A., Djekic, I., \& Tomic, N. (2015). Legislation, standards and diagnostics as a backbone of food safety assurance in Serbia. British Food Journal, 117(1), $94-108$.

23. Sterns, P. A., Codron, J.-M., \& Reardon, T. (2001). Quality and quality assurance in the fresh produce sector: a case study of European retailers. [Selected Paper]. 2001 Annual meeting, August 5-8, Chicago, IL. American Agricultural Economics Association. 
24. Šapić, S., Furtula, S., \& Durkalić, D. (2018). Prestige and national identity as predictors of food products purchase. Economics of Agriculture, 65(2), 643-657.

25. Theuvsen, L., Plumeyer, C.-H., \& Gawron, J.-C. (2007). Certification systems in the meat industry: Overview and consequences for chain-wide communication. Polish Journal of Food and Nutrition Sciences, 57(4C), 563-569.

26. Vlahović, M., Kavalić, M., Borić, S., Stanisavljev, S., \& Curčić, N. (2016). The impact of the number of retail outlets on the market share of consumer goods' retail brands. Journal of engineering management an Competitiveness (JEMC), 6(1), 3645. 